\title{
Surface modification of polysulfone membranes applied for a membrane reactor with immobilized alcohol dehydrogenase
}

Hoffmann, Christian; Silau, Harald; Pinelo, Manuel; Woodley, John M.; Daugaard, Anders E.

Published in:

Materials Today Communications

Link to article, DOI:

10.1016/j.mtcomm.2017.12.019

Publication date:

2018

Document Version

Peer reviewed version

Link back to DTU Orbit

Citation (APA):

Hoffmann, C., Silau, H., Pinelo, M., Woodley, J. M., \& Daugaard, A. E. (2018). Surface modification of polysulfone membranes applied for a membrane reactor with immobilized alcohol dehydrogenase. Materials Today Communications, 14, 160-168. https://doi.org/10.1016/j.mtcomm.2017.12.019

\section{General rights}

Copyright and moral rights for the publications made accessible in the public portal are retained by the authors and/or other copyright owners and it is a condition of accessing publications that users recognise and abide by the legal requirements associated with these rights.

- Users may download and print one copy of any publication from the public portal for the purpose of private study or research.

- You may not further distribute the material or use it for any profit-making activity or commercial gain

- You may freely distribute the URL identifying the publication in the public portal 


\section{Accepted Manuscript}

Title: Surface modification of polysulfone membranes applied for a membrane reactor with immobilized alcohol dehydrogenase

Authors: Christian Hoffmann, Harald Silau, Manuel Pinelo, John M. Woodley, Anders E. Daugaard

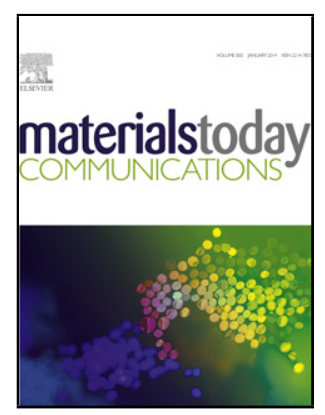

PII:

DOI:

Reference:

S2352-4928(17)30337-9

https://doi.org/10.1016/j.mtcomm.2017.12.019

MTCOMM 258

To appear in:

Received date: $\quad$ 22-12-2017

Accepted date: $\quad 30-12-2017$

Please cite this article as: Christian Hoffmann, Harald Silau, Manuel Pinelo, John M.Woodley, Anders E.Daugaard, Surface modification of polysulfone membranes applied for a membrane reactor with immobilized alcohol dehydrogenase, Materials Today Communications https://doi.org/10.1016/j.mtcomm.2017.12.019

This is a PDF file of an unedited manuscript that has been accepted for publication. As a service to our customers we are providing this early version of the manuscript. The manuscript will undergo copyediting, typesetting, and review of the resulting proof before it is published in its final form. Please note that during the production process errors may be discovered which could affect the content, and all legal disclaimers that apply to the journal pertain. 


\section{Surface modification of polysulfone membranes applied for a membrane reactor with immobilized alcohol dehydrogenase}

Christian Hoffmann ${ }^{a}$, Harald Silau ${ }^{a}$, Manuel Pinelo ${ }^{b}$, John M. Woodley, Anders E. Daugaard ${ }^{a} *$

${ }^{a}$ Danish Polymer Centre, Department of Chemical and Biochemical Engineering, Technical University of Denmark, Søltofts Plads Building 229, DK-2800 Kgs. Lyngby, Denmark

${ }^{\mathrm{b}}$ Center for BioProcess Engineering, Department of Chemical and Biochemical Engineering, Technical University of Denmark, Søltofts Plads Building 229, DK-2800 Kgs. Lyngby, Denmark

${ }^{c}$ Process and Systems Engineering Centre, Department of Chemical and Biochemical Engineering, Technical University of Denmark, Søltofts Plads Building 229, DK-2800 Kgs. Lyngby, Denmark

*Corresponding author: Anders E. Daugaard, E-mail: adt@kt.dtu.dk, Tel: +4545256815 


\title{
Graphical abstract
}

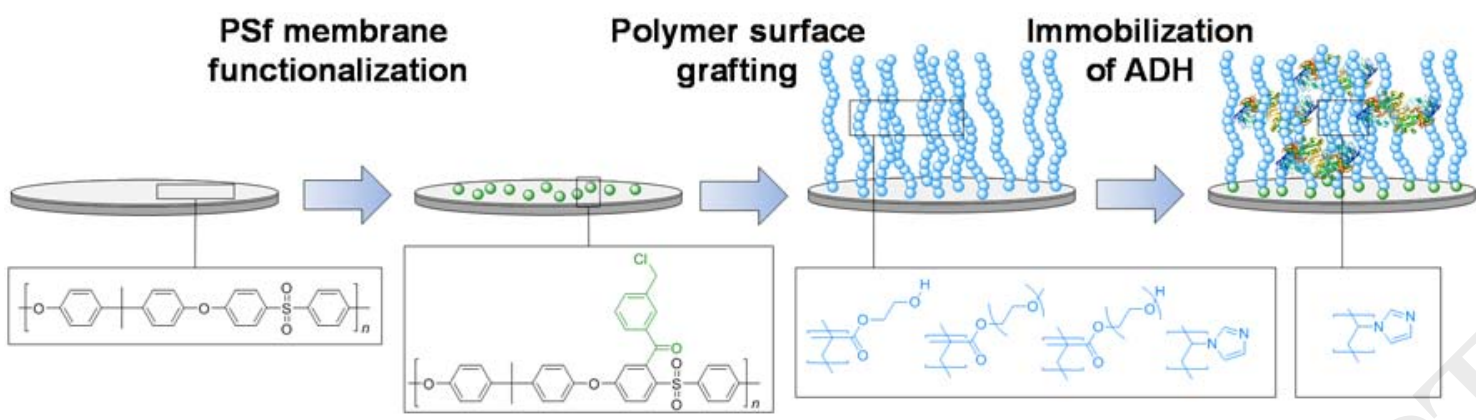

\section{Highlights}

- Versatile functionalization of commercial polysulfone (PSf) membranes

- A two-step lithiation and acylation provides surface functionality on membranes

- Polymer "grafting to" or "grafting from" to control surface properties of membranes

- Polymer grafted membranes are applied as a biocatalytic membrane reactors

- Increased stability of ADH is achieved through immobilization on pVim grafted PSf

\begin{abstract}
Commercially available polysulfone (PSf) membranes with a polypropylene backing are used across a broad range of applications. However, the natural properties of the PSf surface sometimes limit their application. Here we present, how the surface of supported membranes can be heterogeneously activated by lithiation followed by functionalization with acid chlorides at $0{ }^{\circ} \mathrm{C}$, permitting modification of commercial PSf membranes without compromising the mechanical integrity of the membrane. Post-functionalization polymer grafting was illustrated through both, a "grafting from" approach by surface initiated atom transfer radical polymerization (SI-ATRP) and by a "grafting to" approach exploiting $\mathrm{Cu}(\mathrm{I})$ catalyzed 1,3-cycloadditions of alkynes with azides (CuAAC) introducing hydrophilic polymers onto the membrane surface. Poly(1-vinyl imidazole) (pVim) grafted membranes were exploited as support for immobilization of alcohol dehydrogenase $(\mathrm{ADH})$ in a biocatalytic membrane reactor $(\mathrm{BMR})$ and demonstrated substantial improvements in terms of operational enzyme stability compared to immobilization onto pristine membranes.
\end{abstract}

\section{Keywords}

polysulfone membrane; surface functionalization; enzyme immobilization 


\section{Introduction}

Polysulfone (PSf) as a material for polymer membranes has gained considerable importance throughout the past decades due to its outstanding properties, such as the acceptance of a wide $\mathrm{pH}$ range and organic media, as well as very good thermal and mechanical stability. Therefore, PSf membranes have been used in a broad range of applications including gas and liquid separation, ${ }^{1}$ in fuel cells ${ }^{2}$ and ion-exchange processes. ${ }^{3}$ Furthermore, the development of PSf membranes as supports for enzyme immobilization in biocatalytic membrane reactors (BMRs) has demonstrated particular relevance. ${ }^{4}$ The significant advantage of BMRs is the direct combination of a biocatalytic reaction with a separation step. However, in order to achieve a high biocatalytic productivity, both high enzymatic activity and stability are required, which is mainly a function of the type of immobilization, the generated micro-environment between the enzyme and the support as well as the process conditions. ${ }^{5}$ So far, various approaches have been investigated including pressure-driven entrapment into pristine ${ }^{6}$ or modified PSf membranes ${ }^{7-10}$ as well as by cross-linking of entrapped enzymes. ${ }^{11,12}$ Furthermore, immobilization by induced fouling into the skin layer and alternatively in the porous support layer have been studied. ${ }^{13-15}$

In addition to these biocatalytic challenges, pressure-driven membranes generally require high permeability and thus, good anti-fouling properties. High membrane flux and low fouling are directly correlated and can be significantly improved by increasing the hydrophilicity of the membrane surface. ${ }^{16}$ Membrane surface modification has been shown to be a successful route to improve anti-fouling properties ${ }^{17}$ as well as to generate a beneficial environment for immobilized enzymes. ${ }^{18}$ PSf membranes can generally be modified through coating with an additional surface layer, such as hydrophilic poly(ethylene glycol) (PEG) or poly(vinyl alcohol) (PVA) $)^{19,20}$, or by cross-linked hydrogels ${ }^{21,22}$, which demonstrated significantly improved fouling resistance. Currently, there are a few examples of membrane surface coatings being applied for the preparation of biocatalytic membranes, such as the use of a polyethylenimine (PEI) coating on a PSf membrane allowing the immobilization of $\beta$-galactosidase onto the polyelectrolyte layer by adsorption. ${ }^{23}$ The incorporation of PEG into a sodium alginate coating increased simultaneously membrane flux as well as biocatalytic performance of entrapped $\mathrm{ADH} \cdot{ }^{24}$ Alternatively, surface modification by covalent grafting can be used to improve anti-fouling and biocatalytic performance of BMRs, which can be achieved by plasma treatment, UV irradiation or by chemical modification of the surface. Plasma treatment has been used in order to covalently link hydrophilic polymers, such as PEG and poly(acrylic acid) (pAAc) onto PSf membranes. ${ }^{25,26}$ Plasma was also applied for the grafting of amine functional polymers onto PSf, which allowed covalent enzyme immobilization. ${ }^{27}$ Reduced membrane fouling was also achieved through UV initiated grafting of poly(ethylene glycol) methacrylate (PEGMA). ${ }^{28} \mathrm{UV}$-polymerization of acrylic acid (AAc) and acrylamide (AAm) resulted in PSf membranes with improved water permeability and by activation of the carboxylic acid moieties, catalase was covalently immobilized demonstrating improved biocatalytic activity. ${ }^{29}$ Wet chemical methods were also used in order to introduce various functionalities onto PSf surfaces. For instance, Friedel-Crafts catalysts allowed 
chloromethylation, aminomethylation as well as functionalization with propylene oxide. ${ }^{30-32}$ Heterogeneous lithiation with subsequent carboxylation using $\mathrm{CO}_{2}$ and further modification resulted in PSf membranes with either carboxylic acid or acyl fluoride functionality. ${ }^{33,34}$

Additionally to these low molecular weight modifications, surface polymer grafting has been applied, for instance through surface-initiated atom transfer radical polymerization (SI-ATRP) of halogen functionalized PSf surfaces prepared by chloromethylation. This "grafting from" approach substantiated the introduction of hydrophilic polymers and thus, improved anti-fouling properties of the membrane. ${ }^{35,36}$ Alternatively, the use of "Click Chemistry" as a "grafting to" technique permitted the introduction of a large range of different substituents or fully characterized polymers. ${ }^{37}$ As such, the hydrophilicity of PSf membranes has been increased by $\mathrm{Cu}(\mathrm{I})$-catalyzed alkyne azide cycloaddition $(\mathrm{CuAAC})$ between azide functional PSf and terminal alkyne functional zwitterionic and PEG based polymers. ${ }^{38,39}$

The objective of this study was the versatile surface functionalization of commercially available PSf membranes with a polymer backing and their application for the immobilization of enzymes in a BMR with improved biocatalytic performance. A heterogeneous process, combining a lithiation and an acylation step, was targeted to introduce a broad range of low molecular weight functionalities prior to polymer grafting of the membrane surface. The main emphasis is here put on modification of commercially available membranes with a support backing of polypropylene and to develop a process that does not affect the mechanical integrity of the membrane and the support layer. By careful selection of the functional moiety, changes of the surface chemistry were targeted in order to (i) significantly improve the membrane properties, such as increased hydrophilicity and (ii) to create a suitable micro-environment for the immobilization of enzymes.

\section{Materials and Methods}

\subsection{Materials}

Polysulfone membranes (PSf-1) GR61PP (20 kDa MWCO and GR40PP (100 kDa MWCO) were obtained from Alfa Laval. N-butyl lithium (n-BuLi, 2.5 M in hexane), pentadecafluorooctanoyl chloride (97\%), 3(chloromethyl)benzoyl chloride (98\%), methacryloyl chloride (97\%), 1-naphtoyl chloride (97\%), 2-furoyl chloride (95\%), sodium azide (99\%), tetrahydrofuran (THF, $\geq 99 \%$ ), copper(I)chloride (99\%), 2,2' bipyridine (98\%), copper(II)sulfate (99,9\%), (+)-sodium L-ascorbate (NaAsc, 98\%), propargyl 2-bromoisobutyrate

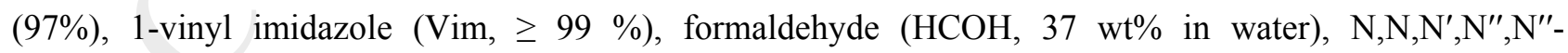
pentamethyldiethylenetriamine (PMDETA), alcohol dehydrogenase from Saccharomyces cerevisiae (ADH, $\geq$ 300 units/mg protein) and $\beta$-Nicotinamide adenine dinucleotide, reduced disodium salt hydrate (NADH, $\geq$ 97\%) were purchased from Sigma Aldrich. Poly(ethylene glycol) methacrylate (PEGMA, $360 \mathrm{~g} \mathrm{~mol}^{-1}$ ), poly(ethylene glycol)methylether metacrylate (MPEGMA, $300 \mathrm{~g} \mathrm{~mol}^{-1}$ ), and 2-hydroxyethyl methacrylate (HEMA; 97\%) were purchased from Sigma Aldrich and passed through a short plug-flow column containing aluminum oxide (Sigma-Aldrich, activated, basic, Brockmann I, standard grade) prior to using for SI-ATRP 
or regular ATRP. Diethyl ether (Sigma-Aldrich, 99.8\%) was dried with molecular sieves (Sigma-Aldrich, 4 $\AA$ ) prior to using for lithiation reactions. All other chemicals were acquired from Sigma Aldrich were used as received.

\subsection{Characterization}

NMR spectroscopy was carried out on a Bruker Avance $300 \mathrm{MHz}$ spectrometer. Chemical shifts are given in ppm. Number average molecular weights of the alkyne-pPEGMA were determined by ${ }^{1} \mathrm{H}$ NMR experiments. Additionally, molecular weights and the polydispersity index of alkyne-pPEGMA was estimated by size exclusion chromatography (SEC), using a Viscotek GPCmax VE-2001 equipped with a Viscotek TriSEC Model 302 triple detector array (refractive index (RI) detector, viscometer detector, and laser light-scattering detector with a light wavelength of $670 \mathrm{~nm}$ and measuring angles of $90^{\circ}$ and $7^{\circ}$ ) and a Knauer K-2501 UV detector using two PLgel mixed-D columns from Polymer Laboratories (PL). The samples were run in THF at $30^{\circ} \mathrm{C}\left(1 \mathrm{~mL} \mathrm{~min}^{-1}\right)$. Molecular weights were calculated using polystyrene (PS) standards from PL. Differential scanning calorimetry (DSC) was performed using a TA instruments Discovery DSC at a heating and cooling rate of $10^{\circ} \mathrm{C} \mathrm{min}^{-1}$. The melting temperatures $\left(\mathrm{T}_{\mathrm{m}}\right)$ are reported as the peak temperatures of the endothermic melting peaks. Glass transition temperatures $\left(\mathrm{T}_{\mathrm{g}}\right.$ 's) were measured at the inflection point. Fourier transform infrared (FT-IR) spectroscopy was carried out using a Nicolet iS50 FT-IR fitted with a diamond crystal attenuated total reflection accessory (ATR), which operated at a resolution of $4 \mathrm{~cm}^{-1}$ and 32 scans per measurement and was used to identify chemical modifications made by surface functionalization. XPS experiments were conducted on a Thermo Fisher Scientific K-Alpha (East Grinstead, UK). Large area surface analysis used a $400 \mu \mathrm{m}$ spot of monochromatized aluminum K $\alpha$ radiation, following which survey (pass energy $200 \mathrm{eV}$ ) and high-resolution (pass energy $50 \mathrm{eV}$ ) spectra for relevant elements were acquired. Data analyses of the obtained XPS spectra were performed using the Avantage software package as provided by the manufacturer. Advancing and receding water contact angles (WCAs) of the PSf membrane surfaces were determined by using a Dataphysics Contact Angle System OCA20. Each surface was tested via the dynamic sessile drop method at $23^{\circ} \mathrm{C}$, and the average value was determined from three different measurements. For Scanning Electron Microscopy, the membranes were submerged in liquid nitrogen and broken by bending with two precooled tweezers. Subsequently, the samples were dried at room temperature and mounted onto a sample holder and coated with a thin gold film using a sputter coater (Cressington, model 208HR). The cross-sectional scanning electron micrographs were recorded with a FEI Quanta 200 FEG microscope and the secondary electron signal was recorded at $5 \mathrm{keV}$ with an Everhart-Thornley detector.

Membrane permeability measurements were carried out in a stirred cell (Amicon 8050, Millipore, USA), using a fixed stirring speed at $100 \mathrm{rpm}$ and an effective membrane surface area of $13.4 \mathrm{~cm}^{2}$. The cells were filled with $40 \mathrm{~mL}$ of phosphate buffer $(0.1 \mathrm{M}, \mathrm{pH} 7)$. A constant nitrogen pressure of 2 bar was maintained while collecting permeate into a beaker until 13 to $25 \mathrm{~mL}$ of permeate was collected. Placing the beaker on an 
electronic balance allowed for monitoring the permeate flux and, consequently, permeability (permeate density was defined as $1 \mathrm{~g} \mathrm{~mL}^{-1}$ ). The permeate flux was calculated according to the following equation:

$$
\text { Flux }=\frac{V}{t S}
$$

where $\mathrm{V}$ is the volume of permeate solution in $\mathrm{mL} ; \mathrm{t}$ is the time of the flux experiment in $\mathrm{h}$ and $\mathrm{S}$ is the effective membrane area in $\mathrm{m}^{2}$.

Subsequently the permeability was calculated as followed:

$$
\text { Permeability }=\frac{\text { Flux }}{P}
$$

where $\mathrm{P}$ is the applied $\mathrm{N}_{2}$ pressure to the membrane in bar. One-way ANOVA analysis in order to calculate the statistical significance of the various permeabilities was conducted in Origin (OriginLab Corporation). Statistical significance between the results was established at $\mathrm{p}<0.05$.

\subsection{General procedure for preparation of activated PSf membrane (PSf-2a)}

In a general activation procedure, a piece of PSf-1 $\left(2 \times 2 \mathrm{~cm}^{2}, 0.216 \mathrm{~g}\right)$ was first submerged in ethanol for $2 \mathrm{~h}$, then in diethyl ether for $0.5 \mathrm{~h}$. Thereafter, it was transferred into a pre-dried schlenk tube under nitrogen atmosphere, which was then evacuated and back-filled with $\mathrm{N}_{2}$ three times. Diethyl ether $(20 \mathrm{~mL})$ was added under stirring, and $\mathrm{n}-\mathrm{BuLi}\left(0.1 \mathrm{~mL}, 0.25 \mathrm{mmol}, 1.2 \mathrm{mmol} \mathrm{g}^{-1}\right.$ membrane $)$ was added dropwise at room temperature. The reaction mixture was stirred for $2 \mathrm{~h}$. The membrane surface changed colour from white to light yellow. Then, the reaction was cooled down to $0^{\circ} \mathrm{C}$, and pentadecafluorooctanoyl chloride $(0.08 \mathrm{~mL}, 0.31 \mathrm{mmol})$ was added slowly. After continuing stirring for another $60 \mathrm{~min}$, the reaction was quenched by adding ethanol (appr. $20 \mathrm{~mL}$ ). The reacted membrane was removed from the reaction flask and thoroughly rinsed with ethanol before drying in an oven in vacuo at room temperature.

PSf-2a (1) IR $\left(\mathrm{cm}^{-1}\right)$ : $2971(\mathrm{C}-\mathrm{H}), 1804(\mathrm{C}=\mathrm{O}), 1750(\mathrm{C}=\mathrm{O}), 1585\left(\mathrm{C}=\mathrm{C}_{\text {arom }}\right), 1502\left(\mathrm{C}=\mathrm{C}_{\text {arom }}\right), 1488\left(\mathrm{C}-\mathrm{H}_{\text {arom }}\right)$,

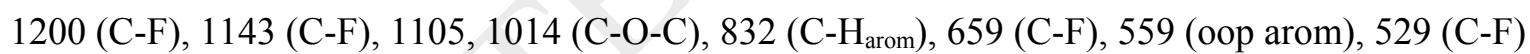

Synthesis of PSf-2b. Compound PSf-2b was synthesized in accordance with the general procedure in which PSf-1 (7x5 cm $2,1.034 \mathrm{~g})$, diethyl ether $(100 \mathrm{~mL}), \mathrm{n}$-BuLi $\left(2.0 \mathrm{~mL}, 5.0 \mathrm{mmol}, 4.9 \mathrm{mmol} \mathrm{g}{ }^{-1}\right.$ membrane), and methacryloyl chloride $(0.65 \mathrm{~mL}, 6.5 \mathrm{mmol})$ were used.

PSf-2b IR $\left(\mathrm{cm}^{-1}\right): 2970(\mathrm{C}-\mathrm{H}), 1731(\mathrm{C}=\mathrm{O}), 1675\left(\mathrm{C}=\mathrm{O} / \mathrm{C}=\mathrm{C}_{\text {alkene }}\right), 1585\left(\mathrm{C}=\mathrm{C}_{\text {arom }}\right), 1503\left(\mathrm{C}=\mathrm{C}_{\text {arom }}\right), 1295(\mathrm{C}-$ O), 1229 (C-O-C), 1149, 1014 (C-O-C), 558 (oop arom).

Synthesis of PSf-2c. Compound PSf-2c was synthesized in accordance with the general procedure in which PSf-1 (12 pieces à $\left.5 \times 5 \mathrm{~cm}^{2}, 5.3 \mathrm{~g}\right)$, diethyl ether (400 mL), n-BuLi (10.6 mL, $26.5 \mathrm{mmol}, 5.0 \mathrm{mmol} \mathrm{g}{ }^{-1}$ membrane), and 3-(chloromethyl)benzoyl chloride $(4.6 \mathrm{~mL}, 31.7 \mathrm{mmol})$ were used. An inert atmosphere was achieved in this case through bubbling with $\mathrm{N}_{2}$ for $15 \mathrm{~min}$, before adding $\mathrm{n}$-BuLi.

PSf-2c IR (cm $\left.{ }^{-1}\right): 2967(\mathrm{C}-\mathrm{H}), 1732(\mathrm{C}=\mathrm{O}), 1680(\mathrm{C}=\mathrm{O}), 1585\left(\mathrm{C}=\mathrm{C}_{\text {arom }}\right), 1502\left(\mathrm{C}=\mathrm{C}_{\text {arom }}\right), 1488\left(\mathrm{C}-\mathrm{H}_{\text {arom }}\right)$,

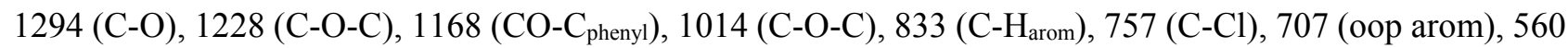
(oop arom). 
Synthesis of PSf-2d. Compound PSf-2d was synthesized in accordance with the general procedure in which PSf-1 (2x2 cm², $0.254 \mathrm{~g})$, diethyl ether $(20 \mathrm{~mL})$, n-BuLi (0.5 mL, $1.3 \mathrm{mmol}, 4.9 \mathrm{mmol} \mathrm{g}{ }^{-1}$ membrane), and 1naphthoyl chloride $(0.25 \mathrm{~mL}, 1.6 \mathrm{mmol})$ were used.

PSf-2d IR ( $\left.\mathrm{cm}^{-1}\right): 2967(\mathrm{C}-\mathrm{H}), 1726(\mathrm{C}=\mathrm{O}), 1670(\mathrm{C}=\mathrm{O}), 1584\left(\mathrm{C}=\mathrm{C}_{\text {arom }}\right), 1504\left(\mathrm{C}=\mathrm{C}_{\text {arom }}\right), 1296(\mathrm{CO}), 1228$

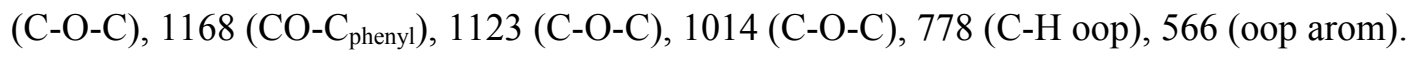

Synthesis of PSf-2e. Compound PSf-2e was synthesized in accordance with the general procedure in which PSf-1 ( $\left.2 \times 2 \mathrm{~cm}^{2}, 0.244 \mathrm{~g}\right)$, diethyl ether ( $\left.20 \mathrm{~mL}\right)$, n-BuLi (0.5 mL, $1.3 \mathrm{mmol}, 5.1 \mathrm{mmol} \mathrm{g}^{-1}{ }_{\text {membrane}}$ ), and 2-furoyl chloride $(0.18 \mathrm{~mL}, 1.7 \mathrm{mmol})$ were used.

PSf-2e IR $\left(\mathrm{cm}^{-1}\right): 2966(\mathrm{C}-\mathrm{H}), 1735(\mathrm{C}=\mathrm{O}), 1668(\mathrm{C}=\mathrm{O}), 1582\left(\mathrm{C}=\mathrm{C}_{\text {arom }}\right), 1503\left(\mathrm{C}=\mathrm{C}_{\text {arom }}\right), 1463,1391(\mathrm{C}=\mathrm{C}$ furyl), 1291 (C-O), 1227 (C-O-C), 1168 (CO-C arom ), 1013 (C-O-C), 929 (C-H furyl), 759 (C-H furyl), 566 (oop arom).

\subsection{Preparation of azide functionalized PSf membrane (PSf-3)}

Into a round-bottom flask, $\mathrm{NaN}_{3}(1.10 \mathrm{~g}, 16.8 \mathrm{mmol}), \mathrm{H}_{2} \mathrm{O}(205 \mathrm{~mL})$, and PSf membrane PSf-2c (four pieces at $5 \times 5 \mathrm{~cm}^{2}$, theor. $1.76 \mathrm{~g}$ ) were added. This mixture was stirred under reflux for $22 \mathrm{~h}$. The membrane was then removed from the reaction bath and thoroughly rinsed with $\mathrm{H}_{2} \mathrm{O}$ before immersing in a $\mathrm{H}_{2} \mathrm{O}$ /ethanol (50:50) bath until further use.

PSf-3 IR ( $\left.\mathrm{cm}^{-1}\right)$ : $2968(\mathrm{C}-\mathrm{H}), 2099\left(\mathrm{~N}_{3}\right) 1734(\mathrm{C}=\mathrm{O}), 1679(\mathrm{C}=\mathrm{O}), 1585\left(\mathrm{C}=\mathrm{C}_{\text {arom }}\right), 1503\left(\mathrm{C}=\mathrm{C}_{\text {arom }}\right), 1294$ (CO), 1230 (C-O-C), 1168 (CO-C phenyl $_{1}$ ), 1014 (C-O-C), 833 (C-Harom), 707 (oop arom), 558 (oop arom).

\subsection{General procedure for the preparation of grafted PSf membrane via SI-ATRP (PSf-4a)}

In a typical grafting experiment, $\mathrm{CuCl}(107 \mathrm{mg}, 1.07 \mathrm{mmol})$ and 2,2' bipyridine (347 $\mathrm{mg}, 2.20 \mathrm{mmol})$ were introduced into a round-bottom flask. The flask was evacuated and backfilled with $\mathrm{N}_{2}$ three times. Then, HEMA ( $8.15 \mathrm{~mL}, 8.75 \mathrm{~g}, 65.9 \mathrm{mmol}$ ), ethanol, and water (4 $\mathrm{mL}$ of each, bubbled with $\mathrm{N}_{2}$ for 60 min prior to use) were introduced. After 50 min of purging with $\mathrm{N}_{2}$, this mixture was transferred under $\mathrm{N}_{2}$ into a schlenk tube equipped with a PSf membrane PSf-2c $\left(5 \times 5 \mathrm{~cm}^{2}\right.$, appr. $\left.0.44 \mathrm{~g}\right)$ and kept in an inert atmosphere. The reaction flask was then heated up to $35^{\circ} \mathrm{C}$, and the polymerization was allowed to proceed for 180 min before being stopped by removing the membrane from the polymerization bath. The substrate was thoroughly rinsed with water and kept immersed in a $\mathrm{H}_{2} \mathrm{O} /$ ethanol (50:50) bath until further use.

PSf-4a IR ( $\left.\mathrm{cm}^{-1}\right)$ : $3443(\mathrm{O}-\mathrm{H}), 2964(\mathrm{C}-\mathrm{H}), 1726(\mathrm{C}=\mathrm{O}), 1682(\mathrm{C}=\mathrm{O}), 1585\left(\mathrm{C}=\mathrm{C}_{\text {arom }}\right), 1503\left(\mathrm{C}=\mathrm{C}_{\text {arom }}\right), 1234$ (C-O-C), 1152 (C-O), 1079 (C-OH), 1014 (C-O-C), 832 (C-Harom), 757 (C-Cl), 707 (oop arom), 567 (oop arom).

Synthesis of PSf-4b. Compound PSf-4b was synthesized in accordance with the general procedure in which PSf-2c (5x5 cm², appr. $0.44 \mathrm{~g}$ ) was modified using $\mathrm{CuCl}$ (107 mg, $1.07 \mathrm{mmol}$ ), 2,2' bipyridine (347 mg, 2.20 mmol), MPEGMA (18.5 mL, $19.44 \mathrm{~g}, 60.5 \mathrm{mmol})$, ethanol, and water $\left(9.5 \mathrm{~mL}\right.$ of each, bubbled with $\mathrm{N}_{2}$ for $60 \mathrm{~min}$ prior to use). 
PSf-4b IR ( $\left.\mathrm{cm}^{-1}\right)$ : $2966(\mathrm{C}-\mathrm{H}), 1729(\mathrm{C}=\mathrm{O}), 1680(\mathrm{C}=\mathrm{O}), 1585\left(\mathrm{C}=\mathrm{C}_{\text {arom }}\right), 1503\left(\mathrm{C}=\mathrm{C}_{\text {arom }}\right), 1294,1236$ (C-OC), 1150 (C-O), 1013 (C-O-C), 833 (C-Harom), 707 (C-Cl), 559 (oop arom).

Synthesis of PSf-4c. Compound PSf-4b was synthesized in accordance with the general procedure in which PSf-2c (5x5 cm², appr. $0.44 \mathrm{~g}$ ) was modified using $\mathrm{CuCl}$ (107 mg, $1.07 \mathrm{mmol}$ ), 2,2' bipyridine (347 mg, 2.20 mmol), PEGMA (20.8 mL, $23.01 \mathrm{~g}, 56.7 \mathrm{mmol}$ ), ethanol, and water (each $10.5 \mathrm{~mL}$, bubbled with $\mathrm{N}_{2}$ for 60 min prior to use).

PSf-4c IR ( $\left.\mathrm{cm}^{-1}\right): 3367(\mathrm{O}-\mathrm{H}), 2965(\mathrm{C}-\mathrm{H}), 1728(\mathrm{C}=\mathrm{O}), 1678(\mathrm{C}=\mathrm{O}), 1585\left(\mathrm{C}-\mathrm{C}_{\text {arom }}\right), 1503$ (C-C $\left.\mathrm{C}_{\text {arom}}\right), 1230$ (C-O-C), 1152 (C-O), 1013 (C-O-C), 834 (C-Harom), 757 (C-Cl), 707 (oop arom), 558 (oop arom).

Synthesis of PSf-4d. Compound PSf-4d was synthesized in accordance with the general procedure in which PSf-2c ( $5 \times 5 \mathrm{~cm}^{2}$, appr. $0.44 \mathrm{~g}$ ) was modified using $\mathrm{CuCl}(107 \mathrm{mg}, 1.07 \mathrm{mmol}), 2,2$ ' bipyridine (347 mg, 2.20 $\mathrm{mmol}$ ), Vim (18.0 mL, $18.7 \mathrm{~g}, 199 \mathrm{mmol}$ ), ethanol, and water (each $12 \mathrm{~mL}$, bubbled with $\mathrm{N}_{2}$ for 60 min prior to use).

PSf-4d IR ( $\left.\mathrm{cm}^{-1}\right): 3384(\mathrm{O}-\mathrm{H}), 2965(\mathrm{C}-\mathrm{H}), 1728(\mathrm{C}=\mathrm{O}), 1678(\mathrm{C}=\mathrm{O}), 1585\left(\mathrm{C}-\mathrm{C}_{\text {arom }}\right), 1503$ (C-C $\left.\mathrm{C}_{\text {arom }}\right), 1235$ (C-O-C), 1150 (C-O), 1013 (C-O-C), 832 (C-Harom), 710 (oop arom), 558 (oop arom).

\subsection{Synthesis of alkyne polyPEGMA}

In a typical ATRP experiment, $\mathrm{CuCl}(20.2 \mathrm{mg}, 0.200 \mathrm{mmol})$ was added into a schlenk tube equipped with a stirring bar and a rubber septum, which was evacuated and back-filled with $\mathrm{N}_{2}$ three times. Subsequently, PEGMA (2.6 mL, $8.0 \mathrm{mmol})$, water $(7.8 \mathrm{~mL})$, and methanol $(7.8 \mathrm{~mL})$ were added and two freeze-pump-thaw cycles were performed. PMDETA ( $42 \mu \mathrm{L}, 0.20 \mathrm{mmol}$ ) was added and an additional freeze-pump-thaw cycle was carried out. Then, propargyl-2-bromoisobutyrate $(32 \mu \mathrm{L}, 0.20 \mathrm{mmol})$ was added followed by a final freeze-pump-thaw cycle. Polymerization was run at $25^{\circ} \mathrm{C}$ for $90 \mathrm{~min}$. Finally, the product was concentrated in vacuo and precipitated three times from THF into diethyl ether. Drying of the precipitate under vacuum conditions led to a light-blue, highly viscous oil as the targeted product ( $\mathrm{m}=1.44 \mathrm{~g}, 49 \%$ yield).

$\mathrm{T}_{\mathrm{g}}\left({ }^{\circ} \mathrm{C}\right):-49.2$ (DSC); $\mathrm{M}_{\mathrm{n}}\left(\mathrm{g} \mathrm{mol}^{-1}\right): 2500$ (SEC), $1900\left({ }^{1} \mathrm{H}\right.$ NMR); $\mathrm{M}_{\mathrm{w}} / \mathrm{M}_{\mathrm{n}}: 1.06$ (SEC); IR ( $\left.\mathrm{cm}^{-1}\right): 3464$ (O-

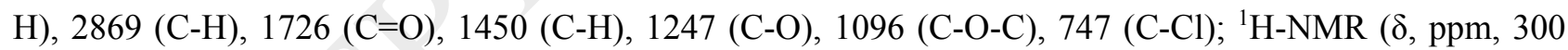
$\mathrm{MHz}, \mathrm{CDCl}_{3}$ ): 4.05 (br s, $\left.10.5 \mathrm{H}\right), 3.66$ (br m, 106H), 2.22 (s, 1H), 1.13 (m, $\left.19 \mathrm{H}\right)$.

\subsection{Preparation of grafted PSf membrane via CuAAC (PSf-5)}

Alkyne-pPEGMA $(0.4131 \mathrm{~g}, 0,217 \mathrm{mmol}), \mathrm{H}_{2} \mathrm{O}(18 \mathrm{~mL})$, aqueous $\mathrm{CuSO}_{4}$ solution $(0.890 \mathrm{~mL}, 0.1 \mathrm{M}, 0.089$ $\mathrm{mmol})$, and aqueous sodium ascorbate $(1.78 \mathrm{~mL}, 0.1 \mathrm{M}, 0.178 \mathrm{mmol})$ were added under stirring into a reaction vial. After 30 minutes, the slightly milky reaction mixture turned yellow and the PSf membrane PSf-3 (5x5 $\mathrm{cm}^{2}$ ) was introduced. After stirring for $14 \mathrm{~h}$, the colour of the reaction mixture changed to brown and the reacted membrane was removed, thoroughly rinsed with water, and kept immersed in a $\mathrm{H}_{2} \mathrm{O} /$ ethanol (50:50) bath until further use.

PSf-5 IR $\left(\mathrm{cm}^{-1}\right)$ : $3453(\mathrm{O}-\mathrm{H}), 2965(\mathrm{C}-\mathrm{H}), 2100\left(\mathrm{~N}_{3}\right), 1731(\mathrm{C}=\mathrm{O}), 1679(\mathrm{C}=\mathrm{O}), 1585\left(\mathrm{C}-\mathrm{C}_{\text {arom}}\right), 1503(\mathrm{C}-$ $\mathrm{C}_{\text {arom}}$ ), 1247 (C-O), 1228 (C-O-C), 1013 (C-O-C), 746 (C-Cl), 833 (C-Harom), 707 (oop arom), 559 (oop arom). 


\subsection{Immobilization of alcohol dehydrogenase (ADH) in PSf membranes}

The pristine membrane (PSf-1) was prior to alcohol dehydrogenase (ADH) immobilization submerged in ethanol for $2 \mathrm{~h}$ and subsequently rinsed with deionized water. Modified membranes were stored in ethanol/water (50:50 vol\%) and rinsed with deionized water prior to immobilization, following the instructions of the manufacturers. A round PSf membrane $(\mathrm{r}=2.25 \mathrm{~cm})$ was placed in an Amicon 8050 stirred cell and 45 $\mathrm{ml}$ of a phosphate buffer solution $(0,1 \mathrm{M}, \mathrm{pH}=7.0)$ containing $\mathrm{ADH}(100 \mathrm{mg} / \mathrm{L})$ was added. The pressure driven immobilization was conducted under a pressure of 1.5 bar and stirring at $100 \mathrm{rpm}$. After $44 \mathrm{ml}$ of ADH solution were collected, $10 \mathrm{~mL}$ phosphate buffer was added. After collecting further $10 \mathrm{~mL}$ of permeate, a second portion $(35 \mathrm{~mL})$ of phosphate buffer was flushed through the membrane until a final permeate volume of 88 $\mathrm{mL}$ was collected. The cumulated permeate was collected in a beaker and after each $4 \mathrm{ml}$, an aliquot of 100 $\mu \mathrm{L}$ was withdrawn for analysis. The concentration of ADH was measured as protein concentration at $280 \mathrm{~nm}$ in microtiter plates ( 96 wells, acrylic from CORNING) using a microtiter plate reader (POLARstar OMEGA from BMG Labtech equipped with an UV-VIS probe).

\subsection{Enzymatic reaction of immobilized ADH}

$50 \mathrm{~mL}$ of a phosphate buffer solution $(0,1 \mathrm{M}, \mathrm{pH}=7.0)$ containing NADH $(100 \mu \mathrm{M})$ and $\mathrm{HCOH}(100 \mathrm{mM})$ was added to the membrane previously immobilized with ADH. A pressure of 1.5 bar and stirring of $100 \mathrm{rpm}$ were used during the filtration. The cumulated permeate was collected in a beaker and after each $4 \mathrm{ml}$, an aliquot of $100 \mu \mathrm{L}$ was withdrawn for analysis. The NADH concentration was determined through absorbance measurements at $340 \mathrm{~nm}$ in microtiter plates (96 wells, acrylic from CORNING) using a microtiter plate reader (POLARstar OMEGA from BMG Labtech equipped with an UV-VIS probe), and was used a measurement of the progression of the reaction.

\section{Results and discussion}

\subsection{Heterogeneous functionalization of polysulfone (PSf) membranes}

Functionalized PSf membranes were prepared by an in situ two-step process. First, commercially available PSf membranes were heterogeneously lithiated using n-butyllithium (n-BuLi) in diethyl ether, followed by acylation using various acid chlorides, as illustrated in Scheme 1. 


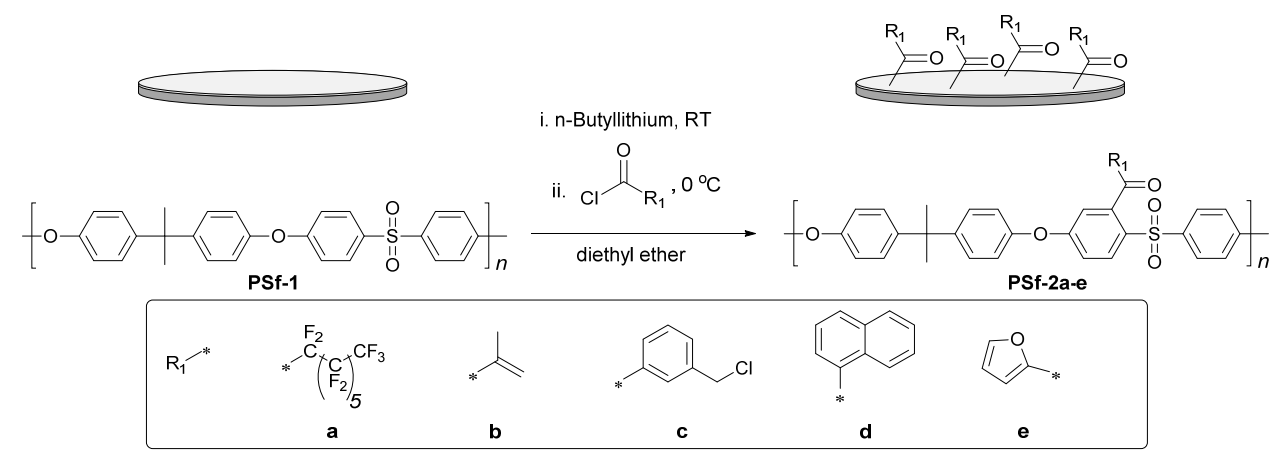

Scheme 1 PSf membranes (PSf-1) were lithiated with n-butyl lithium (n-BuLi), and subsequently acylated using pentadecafluorooctanoyl chloride (a), methacryloyl chloride (b), 3-(chloromethyl)benzoyl chloride (c), 1-naphthoyl chloride (d) and 2furoyl chloride (e) in order to obtain small molecular weight functional PSf membranes PSf-2a-e.

Typically, lithiations are conducted at low temperatures (e.g. $\left.-78^{\circ} \mathrm{C}\right)$ as a result of the reactivity of n-BuLi and the potential degradation of commonly used solvents such as tetrahydrofuran (THF). ${ }^{40}$ In an initial experiment, the commercially available flat sheet membrane, composed of a thin PSf membrane skin layer attached to a polypropylene support, was reacted at $-60^{\circ} \mathrm{C}$. However, these classically low temperature conditions led to the formation of fissures within the material as a consequence of variations in the glass transition temperatures of the PSf and the PP backing (see Figure S1, SEM micrograph). Consequently, a substantial increase in permeability caused by such fissures, which have deleterious effects on separation performance, was observed for the initially modified membranes. Therefore, reaction conditions were modified to accommodate the membrane in terms of solubility as well as mechanical performance, where diethyl ether was identified as the optimal solvent leading to maintained integrity of membrane and support layer after the reaction. Diethyl ether, compared to THF, also allowed the lithiation reaction to be conducted at higher temperatures due to the increased half-life time of diethyl ether compared to THF. Thus, the lithiation step was conducted at room temperature and the subsequent acylation at $0^{\circ} \mathrm{C}$. By reacting the lithiated PSf membrane with pentadecafluorooctanoyl chloride, covalent functionalization of the membrane surface (PSf-2a) was confirmed by the appearance of carbonyl stretches at 1804 and $1750 \mathrm{~cm}^{-1}$ in the respective IR spectra (see Figure 1). 


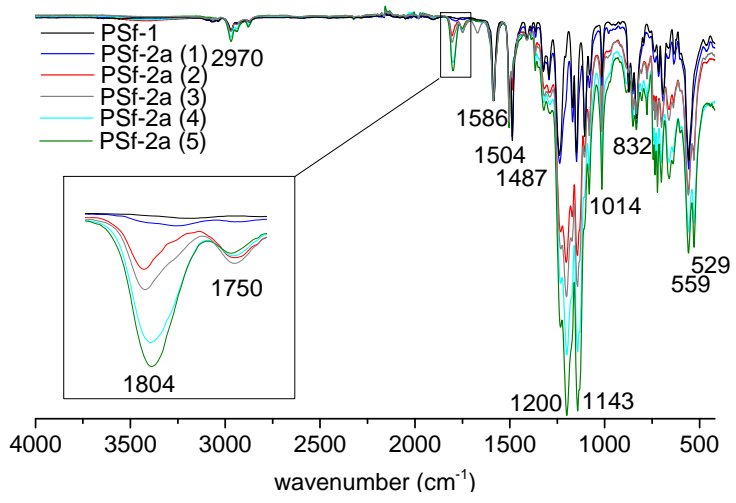

Figure 1 IR spectra of PSf membrane (PSf-1) and activated PSf membranes PSf-2a (1)-(5) with pentadecafluorooctanoyl chloride with

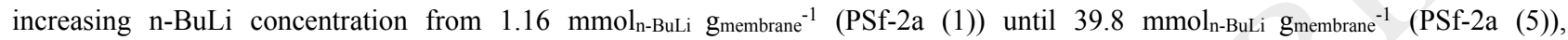
magnification in the wavelength range of 1720 to $1860 \mathrm{~cm}^{-1}$

The generation of two bands in the carbonyl range was explained by the introduction of a ketone group represented as the band at the lower wavenumber (here $1750 \mathrm{~cm}^{-1}$ ), which has been already reported for the homogeneous modification of PSf with n-BuLi and acid chlorides. ${ }^{41}$ The membranes applied in this study were commercially available and thus contain additives, such as e.g. polyvinylpyrrolidone and glycerol that are added during membrane preparation, which may affect the reactivity of the membrane. The membranes were rinsed thoroughly before modification, but after modification, also a second carbonyl band at the higher wavenumber, here $1804 \mathrm{~cm}^{-1}$, assigned to a carbonyl group originating from acylation of hydrophilic residues in the membrane surface was observed. These hydrophilic residues exhibited a weak reactivity towards surface active reagents such as TFAA (Figure S2), which indicated that the surface itself has some hydroxyl groups resulting from the membrane preparation. Thorough washing and Soxhlet extraction of the membranes with ethanol did not allow extraction of the introduced functionalities from the membrane (based on the IR spectra) and both modifications are concluded to be covalently bound to the membranes. The capability of the method was investigated by applying various $\mathrm{n}-\mathrm{BuLi}$ concentrations, ranging from 1.2 to $39.8 \mathrm{mmol}$ of $\mathrm{n}$-BuLi per gram of membrane, followed by acylation using pentadecafluorooctanoyl chloride, leading to PSf-2a (1) to (5). The respective IR spectra (see Figure 1) show an intensity increase in the ester carbonyl band in line with increasing $\mathrm{n}$-BuLi concentration until $20.5 \mathrm{mmol}_{\mathrm{n} \text {-BuLi }} \mathrm{g}_{\text {membrane }}{ }^{-1}$. In contrast, the band at $1750 \mathrm{~cm}^{-1}$ reaches already a steady intensity at $4.5 \mathrm{mmol}_{\mathrm{n}-\mathrm{BuLi}} \mathrm{g}_{\text {membrane }}{ }^{-1}$ (PSf-2a (2)), which could originate from saturation of the heterogeneous aromatic substitution reaction. However, the reaction forming the carbonyl band at $1804 \mathrm{~cm}^{-1}$ is still taking place with additional amounts of $n-B u L i$ and acid chloride, respectively. These results were confirmed by XPS analyses demonstrating an increasing fluorine atom content with increasing $\mathrm{n}-\mathrm{BuLi}$ concentration (see Table 1). 
Table 1 PSf membranes reacted with different concentrations of $\mathrm{n}-\mathrm{BuLi}$ and subsequent acylation using pentadecafluorooctanoyl chloride (PSf-2a), dynamic water contact angles, and fluorine content by XPS

\begin{tabular}{ccccc}
\hline Entry & $\begin{array}{c}\mathbf{c}_{\mathbf{n}-\text { BuLi }} \\
\left(\mathbf{m m o l} \mathbf{g}_{\text {membrane }}{ }^{-1}\right)\end{array}$ & $\begin{array}{c}\theta_{\text {advancing }} \\
\left({ }^{\circ}\right)\end{array}$ & $\begin{array}{c}\theta_{\text {receding }} \\
\left({ }^{\circ}\right)\end{array}$ & $\begin{array}{c}\text { F content } \\
(\mathbf{a t o m \%})\end{array}$ \\
\hline PSf-1 & 0 & 88.1 & 48.7 & - \\
PSf-2a (1) & 1.16 & 81.9 & 40.2 & 8.0 \\
PSf-2a (2) & 4.49 & 99.3 & 54.0 & 29.8 \\
PSf-2a (3) & 10.0 & 109.0 & 58.0 & 30.6 \\
PSf-2a (4) & 20.5 & 110.0 & 72.9 & 36.1 \\
PSf-2a (5) & 39.8 & 119.1 & 64.4 & 42.5 \\
\hline
\end{tabular}

The theoretical fluorine content, assuming each PSf repeating unit reacts once with n-BuLi followed by acid chloride, was calculated as being 27.9 atom $\%$. A fluorine content of 29.8 atom\% was already obtained at 4.5

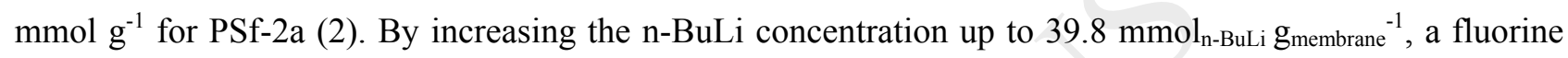
content of up to 42.5 atom\% was achieved, indicating that additional functionalization, besides the known PSf reaction, occurred. These results are in agreement with IR spectroscopy, which confirmed the surface loading. Additionally, WCAs increased from an advancing WCA of $88.1^{\circ}$ and a receding WCA of $48.7^{\circ}$ for the original surface to an advancing WCA of $119.1^{\circ}$ and a receding WCA of $64.4^{\circ}$, respectively, which clearly corroborate the derivatization through an increase in hydrophobicity as a function of fluorine content (see Table 1).

As shown in Scheme 1, the ease and versatility of this heterogeneous modification technique was demonstrated through the selection of various organic acid chlorides in order to introduce a broad range of functionalities, such as methacryl (PSf-2b), 3-(chloromethyl)benzyl (PSf-2c), naphthyl (PSf-2d), and furyl (PSf-2e) groups. For each of these modifications, a concentration of $5 \mathrm{mmol}_{\mathrm{n}-\mathrm{BuLi}} \mathrm{g}_{\text {membrane }}{ }^{-1}$, identified above as the optimal concentration for having a significant impact on surface functionalization, was utilized. IR analysis and the appearance of the previously mentioned carbonyl stretch bands confirmed the reactions(see Figure 2). 


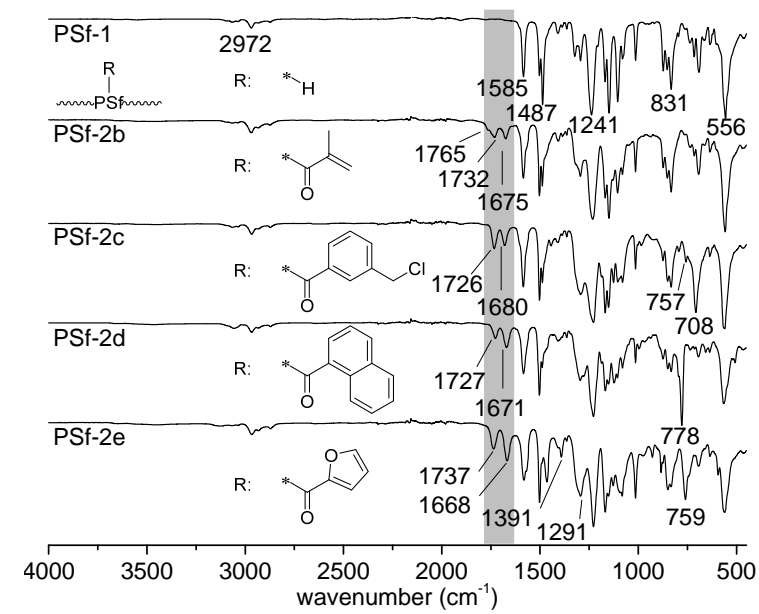

Figure 2 IR spectra of initial PSf membrane (PSf-1) and activated PSf membranes PSf-2 with various acid chlorides, PSf-2b: methacryloyl chloride, PSf-2c: 3-(chloromethyl)benzoyl chloride, PSf-2d: 1-naphthoyl chloride, PSf-2e: 2-furoyl chloride

Additionally, IR bands characteristic to the different functionalities illustrate modifications made to the membrane surface. The methacryloyl-functionalized PSf membranes (PSf-2b) showed the two carbonyl stretches at 1732 and $1675 \mathrm{~cm}^{-1}$, with the latter one appearing within the range of a typical $\mathrm{C}=\mathrm{C}$ stretch. The additional ester was confirmed with the additional carbonyl peak at $1765 \mathrm{~cm}^{-1}$, which originates from the methacryloyl group. The spectrum of PSf-2c, shows in addition to the carbonyl bands $\left(1726 / 1680 \mathrm{~cm}^{-1}\right)$ the introduction of a significant band at 708 and a small band at $757 \mathrm{~cm}^{-1}$ assigned to an aromatic out-of-plane deformation and a carbon-chloride vibration, respectively. The acylation using 1-naphthoyl chloride provided an IR spectrum showing a C-H out-of-plane deformation characteristic for naphthalenes at $778 \mathrm{~cm}^{-1}$ in addition to the respective carbonyl bands at 1727 and $1671 \mathrm{~cm}^{-1}$. 2-Furoyl functionalized PSf membranes offered similar results, with carbonyl stretches at 1737 and $1668 \mathrm{~cm}^{-1}$, while bands at 1391 (furylic $\mathrm{C}=\mathrm{C}$ stretch vibration) and $759 \mathrm{~cm}^{-1}$ (furylic C-H stretch vibration) confirmed the reaction. The introduction of the various functional groups opens up for further derivatization methodologies through, for example, thiol-ene reaction or Aza Michael additions ${ }^{42}$ of methacryl groups ${ }^{43-45}$, whereas furyl groups are known to react in Diels-Alder cycloaddition. ${ }^{46,47}$

\subsection{Polymer modified PSf membranes via "Grafting from" and "Grafting to"}

Chloride functional PSf membranes PSf-2c allowed further polymer grafting directly via SI-ATRP through a "grafting from" approach and after substitution of the chloride by an azide through CuAAC as a "grafting to" approach, as illustrated in Scheme 2. 

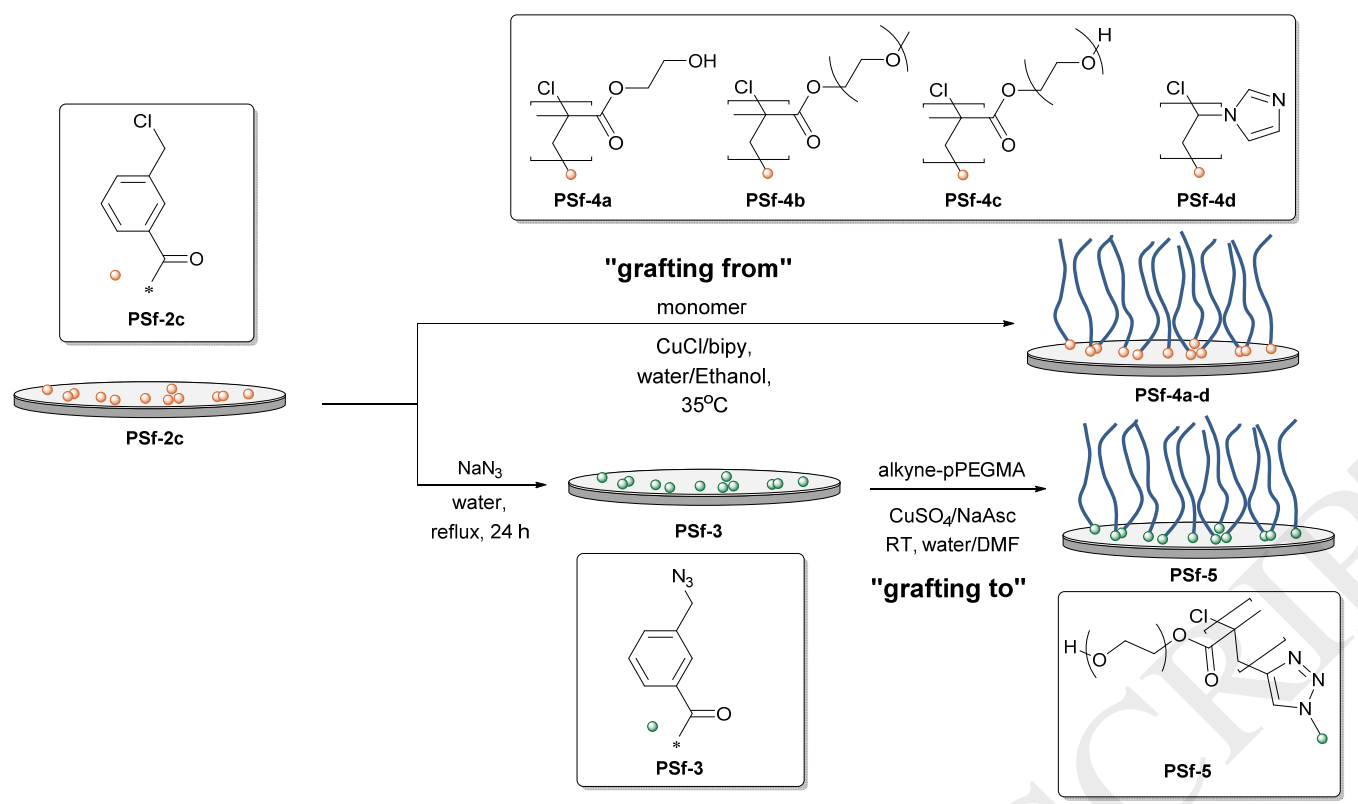

Scheme 2 Two surface grafting approaches: "Grafting from" by SI-ATRP of the chloride functionalized PSf membranes (PSf-2c) to provide PSf-4a-d; azidation of PSf-2c, leading to PSf-3, followed by "Grafting to" through CuAAC with alkyne functionalized pPEGMA, resulting in PSf-5

Therefore, various hydrophilic monomers, such as 2-hydroxyl methacrylate (HEMA) (PSf-4a), methoxy poly(ethylene glycol) methacrylate (MPEGMA) (PSf-4b), PEGMA (PSf-4c) and 1-vinyl imidazole (Vim) (PSf-4d) were reacted onto PSf-2c under SI-ATRP conditions. IR analysis confirmed the reaction by significantly increased intensity in the ester band at $1726 \mathrm{~cm}^{-1}$ compared to the ketone carbonyl band at 1680 $\mathrm{cm}^{-1}$ for the used methacrylates (Figure S3). Furthermore, the appearance of bands related to C-O-C ether at $1100 \mathrm{~cm}^{-1}$ (for PSf-4a, b, c) and hydroxyl groups at $3466 \mathrm{~cm}^{-1}$ (for PSf-2a) provided evidence for the "grafting from" method being efficient. Grafting of poly(1-vinyl imidazole) (pVim) could not conclusively be confirmed by IR. XPS analysis corroborated the polymer grafting via SI-ATRP, as shown in Table 2. 
Table 2 XPS data of activated and polymer grafted PSf membranes

\begin{tabular}{|c|c|c|c|c|c|c|}
\hline Entry & $\begin{array}{c}\text { Functionality on the } \\
\text { membrane }\end{array}$ & $\begin{array}{c}\text { C1s } \\
(\text { atom\%) }\end{array}$ & $\begin{array}{c}\text { O1s } \\
\text { (atom\%) }\end{array}$ & $\begin{array}{c}\text { N1s } \\
(\text { atom\%) }\end{array}$ & $\begin{array}{c}\text { S2p } \\
\text { (atom\%) }\end{array}$ & $\begin{array}{c}\text { Cl2p } \\
\text { (atom\%) }\end{array}$ \\
\hline PSf-1 & - & $\begin{array}{c}82.8 \pm \\
0.2\end{array}$ & $13.1 \pm 0.2$ & - & $4.0 \pm 0.0$ & - \\
\hline PSf-2c & $\mathrm{Cl}$ & $\begin{array}{c}79.9 \pm \\
1.2\end{array}$ & $12.2 \pm 0.3$ & - & $2.2 \pm 0.1$ & $5.7 \pm 1.1$ \\
\hline PSf-4a & pHEMA $^{\mathrm{a}}$ & $\begin{array}{c}72.0 \pm \\
0.5\end{array}$ & $24.3 \pm 0.9$ & - & $1.4 \pm 0.1$ & $1.9 \pm 0.2$ \\
\hline PSf- $4 b$ & pMPEGMA $^{\mathrm{a}}$ & $\begin{array}{c}72.2 \pm \\
0.8\end{array}$ & $24.9 \pm 0.8$ & - & $1.7 \pm 0.2$ & $1.0 \pm 0.1$ \\
\hline PSf-4c & pPEGMA $^{\mathrm{a}}$ & $\begin{array}{c}77.4 \pm \\
0.1\end{array}$ & $19.0 \pm 0.3$ & - & $2.6 \pm 0.2$ & $0.9 \pm 0.2$ \\
\hline PSf-4d & $\mathrm{pVim}^{\mathrm{a}}$ & $\begin{array}{c}72.9 \pm \\
3.4\end{array}$ & $14.5 \pm 0.7$ & $5.8 \pm 0.2$ & $2.3 \pm 0.2$ & $1.9 \pm 0.7$ \\
\hline PSf-3 & $\mathrm{N}_{3}$ & $\begin{array}{c}78.3 \pm \\
1.8\end{array}$ & $13.5 \pm 0.8$ & 1.4 & $2.3 \pm 0.1$ & $2.4 \pm 0.3$ \\
\hline PSf-5 & pPEGMA $^{\mathrm{b}}$ & $\begin{array}{c}71.3 \pm \\
0.9\end{array}$ & $25.4 \pm 1.7$ & $1.1 \pm 0.4$ & $0.9 \pm 0.2$ & $1.3 \pm 0.2$ \\
\hline
\end{tabular}

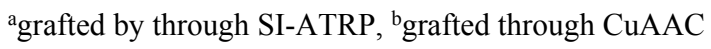

Initially, the introduction of SI-ATRP initiating sites through activation with 3-(chloromethyl)benzyl groups (PSf-2c) was confirmed by the appearance of a significant chloride signal (5.7 atom\%) compared to the pristine membrane (PSf-1). Polymer grafting using HEMA, MPEGMA and PEGMA (PSf-4a,b,c) demonstrated a substantial increase in oxygen content and pVim grafting (PSf-4d) was confirmed through the presence of nitrogen (5.8 atom\%). Furthermore, all polymer grafted surfaces PSf-4a-d, including pVim, showed significantly reduced WCAs confirming an increase in the hydrophilicity (Table S1).

Alternatively, the surface could also be modified through a "grafting to" approach by CuAAC with alkyneterminated polymers (see Scheme 2). Initially, the chloride in PSf 2c was substituted with an azide (PSf-3), which showed a clear IR absorption band at around $2100 \mathrm{~cm}^{-1}$, characteristic for the azide $(-\mathrm{N}=\mathrm{N}=\mathrm{N})$ stretch (see Figure S4). The appearance of a nitrogen N1s split peak and a decrease in the chloride C11s peak in the XPS spectrum corroborated the substitution reaction (see Table 2 and Figure S5). A hydrophilic alkyneterminated pPEGMA (alkyne- pPEGMA) was prepared by ATRP and reacted onto the functional PSf-3 surface in order to obtain the hydrophilic PSf-5 (see Scheme 2). The increase in ester $\mathrm{C}=\mathrm{O}$ stretch intensity at 1726 and the C-O ether band at $1096 \mathrm{~cm}^{-1}$ confirmed the grafting (Figure S4). XPS analysis confirmed the conversion of the azide, where the PSf-5 spectrum showed only a single nitrogen N1s peak (see Figure S6), characteristic of the formation of a triazole group from an azide. ${ }^{48}$ Grafting with the alkyne-pPEGMA resulted in a substantially reduced WCA (see Table S1), comparable to what was observed for the SI-ATRP grafted membranes. 


\subsection{Biocatalytic membrane through immobilization of alcohol dehydrogenase (ADH)}

The water permeability of chloride (PSf-2c) and azide functional (PSf-3) membranes was slightly decreased compared to the pristine PSf membrane. However, polymer grafting through SI-ATRP and CuAAC resulted in a permeability reduction of up to $89 \%$ (see Table S1). Cross-sectional investigation of the pristine (PSf-1), as well as chloride (PSf-2c) and pHEMA (PSf-4a) grafted membranes demonstrated no change in the pore structures of the membrane (see Figure S7). Therefore, it was assumed that the permeability reduction originated from a polymer grafting layer on top of the flat membrane surface. In order to achieve a practical permeability for polymer modified BMRs, PSf membranes with a high MWCO of $100 \mathrm{kDa}$, exhibiting a 10fold higher permeability, were selected for surface grafting. Vim functional surfaces have recently been demonstrated as a particularly effective surface modification for immobilization of horseradish peroxidase on polymer surfaces $^{49}$, as imidazole groups might form beneficial ionic interaction with the enzymes. Therefore pVim was selected for surface modification of the PSf membranes. In this study, ADH from Saccharomyces cerevisiae (EC 1.1.1.1), a zinc metalloenzyme belonging to the family of oxireductases, was used. ${ }^{50}$ ADH catalyzes the the enantioselective oxidation of alcohols to the corresponding aldehyde or ketone, by simultaneously reducing $\beta$-nicotinamide adenine dinucleotide $\left(\mathrm{NAD}^{+}\right)$to $\mathrm{NADH}$ as the cofactor. The $\mathrm{ADH}$ catalyzed reverse reaction of a carbonyl substrate to the corresponding alcohol using NADH is also possible by controlling the reaction conditions - particularly $\mathrm{pH}$-, which can be used in fermentation applications, but also in the third step of sequential reduction of carbon dioxide to methanol. ${ }^{51}$ However, the use of ADH particularly in industry- has been greatly limited by the extremely poor stability of the enzyme. In a recent study, it has been reported that the conversion of a free ADH applied in a BMR dropped to $20 \%$ after just 90 min of operation. ${ }^{52}$ Various immobilization approaches ${ }^{53-55}$ have already been investigated with the goal to improve the enzyme's activity and stability, but none of them have been applied to BMRs.

Here, commercial PSf membranes were functionalized with pVim using short grafting times (5 and $40 \mathrm{~min}$ ) in order to retain high membrane permeability. Subsequently, ADH $\left(0.1 \mathrm{mg} \mathrm{L}^{-1}, 45 \mathrm{~mL}\right.$, in phosphate buffer, $\mathrm{pH}$ 7) was immobilized by pressure driven filtration into the pristine (PSf-1, used as a control) as well as into the pVim functionalized membranes (PSf-4d-5min and PSf-4d-40min). In an additional rinsing step, phosphate buffer $(40 \mathrm{~mL})$ was passed through the membranes in order to flush out any free enzyme. Eventhough the enzyme has a molecular weight around $150 \mathrm{kDa}$, it is clearly possible to extract non-bound enzyme from all of the membranes, enabling removal of the excess enzyme from the membranes. This indicates that the modification of the membranes only have a minor effect on the size selectivity of the membranes. As expected, enzyme immobilization results in a significant reduction in permeability of the pristine membranes as can be seen in Figure 3A. 

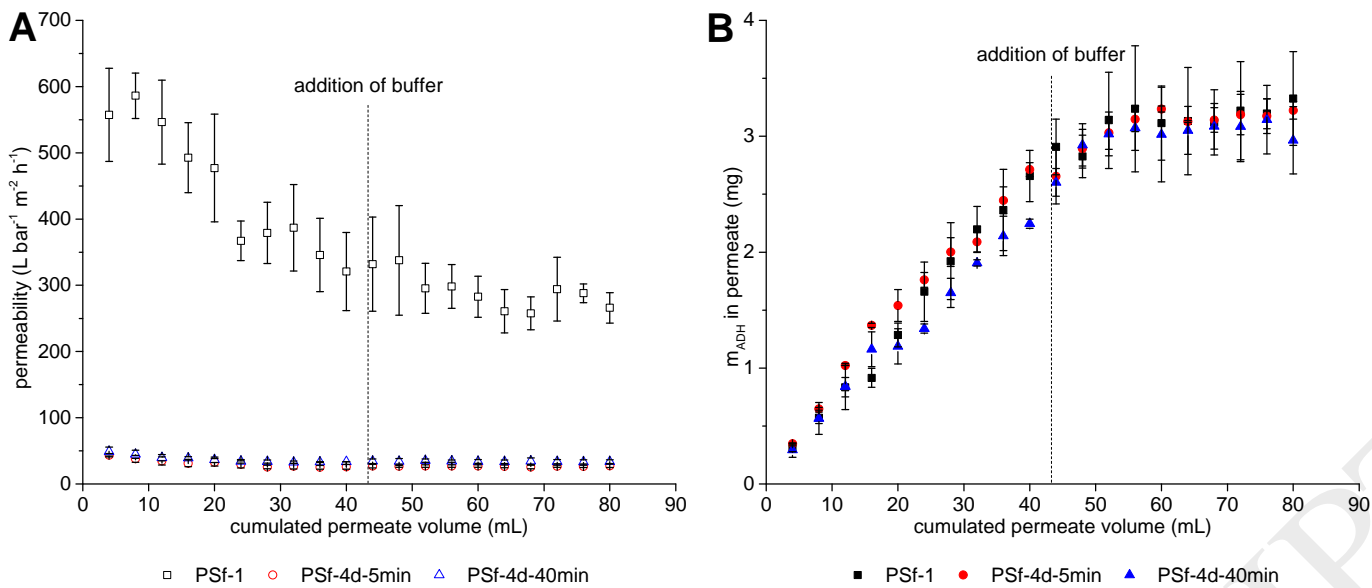

Figure 3 Comparison between permeability (A) and amount of enzyme collected in the permeate (B) during ADH immobilization on pristine $100 \mathrm{kDa}$ PSf membrane (PSf-1) and pVim grafted $100 \mathrm{kDa}$ PSf membranes for 5 and $40 \mathrm{~min}$ (PSf-4d-5min and PSf-4d-40min)

Similarly, a permeability loss of around $31 \%$ was observed for both $\mathrm{pVim}$ functionalized membranes during the immobilization procedure, as shown by initial and final permeability in Table 3. Even though PSf-4d-5min and PSf-4d-40min exhibited reduced permeabilities, their permeability is still at an acceptable level for use as BMRs. The amount of ADH in the permeate throughout the immobilization process (see Figure 3B) showed initially a steady increase indicating enzyme passing through the membrane. The slope of permeated ADH over accumulated permeate volume was very similar for the virgin PSf-1 as well as the pVim modified membranes, indicating that the immobilization did not affect the retention properties of the membrane.

After immobilization, a buffer solution was run through the membrane to ensure that excess ADH was flushed out of the membrane and the amount of immobilized enzyme was determined as the difference between the applied ADH stock solution and the final amount in the permeate. In pristine membranes $0.68 \pm 0.25 \mathrm{mg} \mathrm{ADH}$ could be immobilized, though high variations in permeability and enzyme loading were observed for the pristine membranes. Comparatively, the pVim grafted membranes could adsorb a higher amount of enzyme and showed a higher reproducibility of the membrane performance, as indicated by the lower standard deviation of all the experiments (see Table 3 and Figure 3A).

Table 3 Membrane performance and enzyme loading during immobilization of ADH for pristine and pVim grafted $100 \mathrm{kDa}$ PSf membranes

\begin{tabular}{|c|c|c|c|c|c|}
\hline Entry & $\begin{array}{l}\text { Membrane } \\
\text { modification }\end{array}$ & $\begin{array}{c}\text { Initial membrane } \\
\text { permeability } \\
\left(\mathrm{L} \mathrm{m}^{-2} \mathrm{~h}^{-1} \mathrm{bar}^{-1}\right)\end{array}$ & $\begin{array}{c}\text { Final membrane } \\
\text { permeability } \\
\left(\mathbf{L ~ m}^{-2} \mathbf{h}^{-1} \text { bar }^{-1}\right)\end{array}$ & $\begin{array}{l}\text { Enzyme } \\
\text { loading } \\
(\mathrm{mg})\end{array}$ & $\begin{array}{l}\text { Enzyme loading } \\
\quad\left(\mathrm{mg} \mathrm{cm} \mathrm{cm}^{-2}\right)\end{array}$ \\
\hline PSf-1 & pristine & $557 \pm 70$ & $266 \pm 23$ & $0.68 \pm 0.25$ & $0.051 \pm 0.019$ \\
\hline PSf-4d-5min & pVim & $43.5 \pm 2.5$ & $27.6 \pm 2.7$ & $0.98 \pm 0.06$ & $0.073 \pm 0.005$ \\
\hline PSf-4d-40min & pVim & $49.0 \pm 6.9$ & $33.7 \pm 3.0$ & $1.05 \pm 0.03$ & $0.079 \pm 0.002$ \\
\hline
\end{tabular}


The activity of the immobilized ADH was determined by use of the enzyme catalyzed reduction of formaldehyde $(\mathrm{HCOH})$ to methanol $\left(\mathrm{CH}_{3} \mathrm{OH}\right)$ and the simultaneous oxidation of $\mathrm{NADH}$ to $\mathrm{NAD}^{+}$. All of the membranes displayed a constant permeability during the activity tests as shown in Figure 4A, which confirmed a mechanically stable grafting of the membranes as well as that the substrate does not change the properties of the membrane.
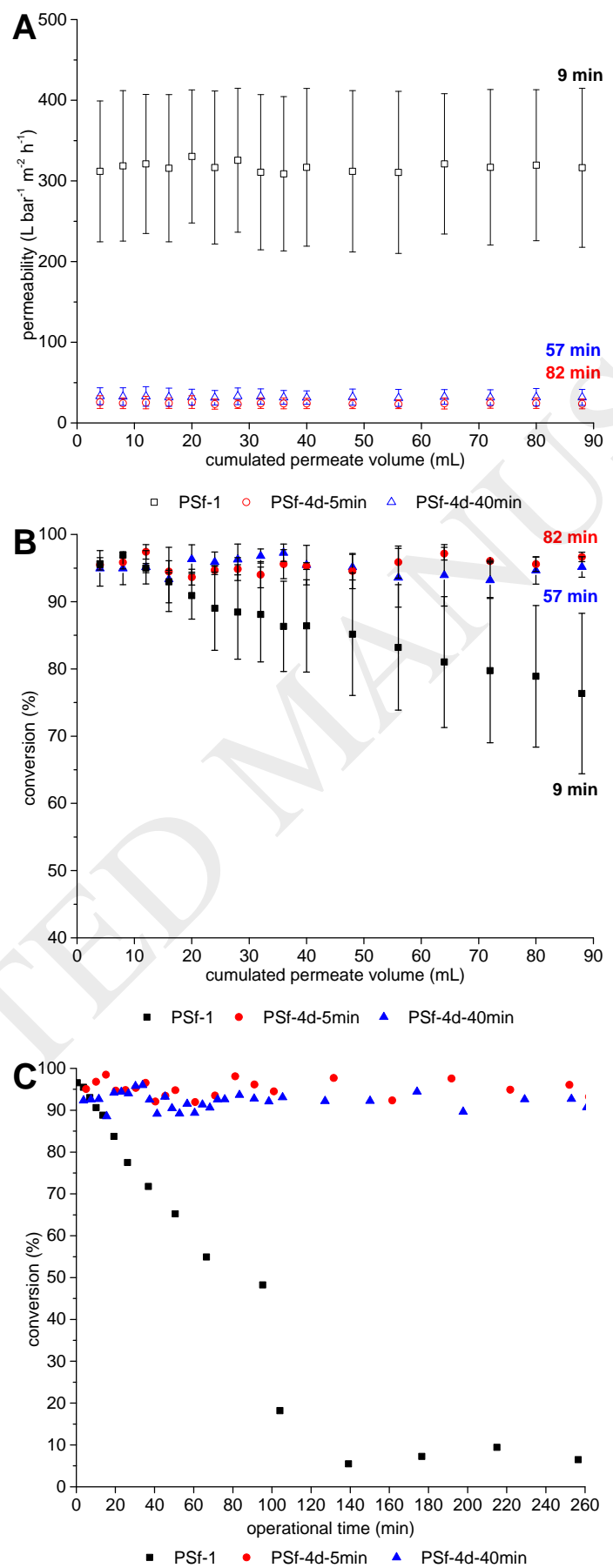

Figure 4 Permeability (A) during enzymatic reaction catalysed by immobilized ADH on pristine $100 \mathrm{kDa}$ PSf membrane (PSf-1) and pVim grafted $100 \mathrm{kDa}$ PSf membranes for 5 and $40 \mathrm{~min}$, NADH conversion versus (B) cumulative permeate volume and (C) versus operation time 
The conversion was determined spectrophotometrically through absorbance measurements of NADH at a wavelength of $340 \mathrm{~nm}$ and is presented in Figure 4B and Figure 4C. For ADH immobilized in the pristine membrane, a substantial decrease in conversion from $94 \%$ to $76 \%$ was observed after 9 min of reaction ( 88 $\mathrm{mL}$ permeate), which indicated enzyme deactivation in the pristine PSf membrane during the early stage of the reaction. Additionally, high variations in conversion were observed, which were attributed to the differences in enzyme loading of the pristine membrane. This could also be related to a higher flow for the pristine systems and a resulting substrate breakthrough during the test, though the tendency of a reduced conversion is clearly seen. Collection of a similar volume of permeate from the polymer grafted membranes showed that these had a high enzymatic activity (conversion $>94 \%$ ) with no apparent reduction in activity throughout the test, even though the tests on the modified membranes were conducted for much longer time (57 and $82 \mathrm{~min}$, respectively), due to the reduced permeability. The operational time for $\mathrm{pVim}$ membranes could be extended to 260 min, in which the conversion remained constant (>90\%), as shown in Figure 4C. Compared to this, the pristine PSf membrane was completely deactivated after $140 \mathrm{~min}$. This demonstrates a substantial improvement in biocatalytic stability of the polymer modified membranes compared to the pristine PSf. This outstanding performance compared to the virgin membrane was ascribed to the combination of increased enzyme loading, higher retention time of the substrate and the generation of a beneficial microenvironment supplied by pVim reducing enzyme deactivation within this period and thus improving the biocatalytic performance substantially.

\section{Conclusions}

In this study, a facile and easily conductible methodology has been applied in order to covalently surface modify commercially available PSf membranes. For this purpose, off-the-shelf commercially available PSf flat sheet membranes were heterogeneously lithiated prior to acylation, using various acid chlorides. The prepared membranes are mechanically sound and the process provides access to a high number of functionalities illustrating the versatility of this method. Surface modifications with methacryloyl-, furoyl-, and halogen-containing functional groups open up a broad range of surface grafting reactions for tailoring the surface properties of membranes. Chloride functionalization of the membrane surface allowed polymer grafting by SI-ATRP using hydrophilic monomers such as HEMA, MPEGMA, PEGMA and Vim in a "grafting from" approach. Conversion of anchored chlorides into azide groups offered the possibility for surface functionalization via CuAAC with an alkyne-pPEGMA as a "grafting to" techniques. Both cases resulted in significantly improved membrane hydrophilicity. Immobilization of ADH onto pVim grafted PSf membranes resulted in an increase in enzyme loading compared to virgin PSf membranes. Furthermore, high enzyme activities (conversions $>94 \%$ ) and significantly improved enzyme stability were achieved using pVim grafted membranes. These outstanding performances in terms of activity, stability and permeability suggested their potential as an excellent support for ADH. This toolbox of simple surface activation followed by polymer 
grafting of commercially available PSf membranes opens up for the application of a broad variety of potential polymers to be used for improved BMRs.

\section{Acknowledgements}

The authors wish to thank the Aage and Johanne Louis-Hansens Endowment for financial support.

\section{Appendix. Supplementary information}

Supplementary data contains SEM images, IR and XPS data as well as membrane properties.

\section{Notes}

The authors declare no competing financial interests.

\section{References}

(1) Ulbricht, M. Polymer 2006, 47 (7), 2217-2262.

(2) Jannasch, P. Fuel Cells 2005, 5 (2), 248-260.

(3) Wang, G.; Weng, Y.; Chu, D.; Chen, R.; Xie, D. J. Memb. Sci. 2009, 332 (1-2), 63-68.

(4) Rios, G. M.; Belleville, M. P.; Paolucci, D.; Sanchez, J. J. Memb. Sci. 2004, 242 (1), 189-196.

(5) Mateo, C.; Palomo, J. M.; Fernandez-Lorente, G.; Guisan, J. M.; Fernandez-Lafuente, R. Enzyme Microb. Technol. 2007, 40 (6), 1451-1463.

(6) Mazzei, R.; Giorno, L.; Piacentini, E.; Mazzuca, S.; Drioli, E. J. Memb. Sci. 2009, 339 (1-2), 215-223.

(7) Wang, Z. G.; Wang, J. Q.; Xu, Z. K. J. Mol. Catal. B Enzym. 2006, 42 (1-2), 45-51.

(8) Cano, À.; Minguillón, C.; Palet, C. J. Memb. Sci. 2006, 280 (1-2), 383-388.

(9) Łukowska, E.; Wojciechowsk, C.; Chwojnowski, A.; Dudziński, K.; Sabalińska, S.; Ciechanowska, A.; Czapiewska, G. Biocybern. Biomed. Eng. 2012, 32 (2), 77-86.

(10) Ulbricht, M.; Riedel, M.; Marx, U. J. Memb. Sci. 1996, 120, 239-259.

(11) Yujun, W.; Jian, X.; Guangsheng, L.; Youyuan, D. Bioresour. Technol. 2008, 99 (7), 2299-2303.

(12) Zhu, X.-Y.; Chen, C.; Chen, P.-C.; Gao, Q.-L.; Fang, F.; Li, J.; Huang, X.-J. RSC Adv. 2016, 6 (37), 30804-30812.

(13) Luo, J.; Marpani, F.; Brites, R.; Frederiksen, L.; Meyer, A. S.; Jonsson, G.; Pinelo, M. J. Memb. Sci. 2014, 459, 1-11.

(14) Luo, J.; Meyer, A. S.; Jonsson, G.; Pinelo, M. Biochem. Eng. J. 2014, 83, 79-89.

(15) Luo, J.; Meyer, A. S.; Mateiu, R. V; Kalyani, D.; Pinelo, M. ACS Appl. Mater. Interfaces 2014, 6, 22894-22904.

(16) Rana, D.; Matsuura, T. Chem. Rev. 2010, 110, 2448-2471.

(17) Miller, D. J.; Dreyer, D. R.; Bielawski, C. W.; Paul, D. R.; Freeman, B. D. Angew. Chemie - Int. Ed. 
2017, 56 (17), 4662-4711.

(18) Jochems, P.; Satyawali, Y.; Diels, L.; Dejonghe, W. Green Chem. 2011, 13 (7), 1609.

(19) Brink, L. E. S.; Romijn, D. J. Desalination 1990, 78 (2), 209-233.

(20) Hyun, J.; Jang, H.; Kim, K.; Na, K.; Tak, T. J. Memb. Sci. 2006, 282 (1-2), 52-59.

(21) Ju, H.; McCloskey, B. D.; Sagle, A. C.; Kusuma, V. A.; Freeman, B. D. J. Memb. Sci. 2009, 330 (1-2), $180-188$.

(22) Lang, K.; Chowdhury, G.; Matsuura, T.; Sourirajan, S. Journal of colloid and interface science. 1994, pp 239-244.

(23) Gonawan, F. N.; Kamaruddin, A. H.; Abu Bakar, M. Z.; Abd Karim, K. Ind. Eng. Chem. Res. 2016, 55 (1), 21-29.

(24) Marpani, F.; Luo, J.; Mateiu, R. V.; Meyer, A. S.; Pinelo, M. ACS Appl. Mater. Interfaces 2015, 7 (32), $17682-17691$.

(25) Song, Y.-Q.; Sheng, J.; Wei, M.; Yuan, X.-B. J. Appl. Polym. Sci. 2000, 78, 979-985.

(26) Wavhal, D. S.; Fisher, E. R. J. Memb. Sci. 2002, 209 (1), 255-269.

(27) Mahlicli, F. Y.; Şen, Y.; Mutlu, M.; Alsoy Altinkaya, S. J. Memb. Sci. 2015, 479, 175-189.

(28) Susanto, H.; Balakrishnan, M.; Ulbricht, M. J. Memb. Sci. 2007, 288 (1-2), 157-167.

(29) Song, H.; Wu, G.; Liu, K. J. Environ. Sci. 2004, 16 (3), 392-396.

(30) Higuchi, A.; Nakagawa, T. J. Appl. Polym. Sci. 1990, 41 (9-10), 1973-1979.

(31) Higuchi, A.; Koga, H.; Nakagawa, T. J. Appl. Polym. Sci. 1992, 46 (3), 449-457.

(32) Breitbach, L.; Hinke, E.; Staude, E. Die Angew. Makromol. Chemie 1991, 184 (3134), 183-196.

(33) Guiver, M. D.; Croteau, S.; Hazlett, J. D.; Kutowy, O. Br. Polym. J. 1990, 23 (1-2), 29-39.

(34) Guiver, M. D.; Black, P.; Tam, C. M.; Deslandes, Y. J. Polym. Sci. 1993, 48, 1597-1606.

(35) Qiu, J.; Zhang, Y.; Shen, Y.; Zhang, Y.; Zhang, H.; Liu, J. Appl. Surf. Sci. 2010, 256 (10), 3274-3280.

(36) Yue, W.-W.; Li, H.-J.; Xiang, T.; Qin, H.; Sun, S.-D.; Zhao, C.-S. J. Memb. Sci. 2013, 446, 79-91.

(37) Kolb, H. C.; Finn, M. G.; Sharpless, K. B. Angew. Chemie 2001, 40 (11), 2004-2021.

(38) Meng, J. Q.; Yuan, T.; Kurth, C. J.; Shi, Q.; Zhang, Y. F. J. Memb. Sci. 2012, 401, 109-117.

(39) Xiang, T.; Wang, R.; Zhao, W.-F.; Sun, S.-D.; Zhao, C.-S. Langmuir 2014, 30 (18), 5115-5125.

(40) Holm, T. Acta Chem. Scand. B 1978, 32, 162-166.

(41) Dimitrov, I.; Takamuku, S.; Jankova, K.; Jannasch, P.; Hvilsted, S. Macromol. Chem. Phys. 2012, 33, $1368-1374$.

(42) Hoffmann, C.; Stuparu, M. C.; Daugaard, A.; Khan, A. J. Polym. Sci. Part A Polym. Chem. 2015, 53 (6), 745-749.

(43) Lowe, A. B. Polym. Chem. 2010, 1 (1), 17-36.

(44) Campos, L. M.; Meinel, I.; Guino, R. G.; Schierhorn, M.; Gupta, N.; Stucky, G. D.; Hawker, C. J. Adv. Mater. 2008, 20 (19), 3728-3733. 
(45) Gupta, N.; Lin, B. F.; Campos, L. M.; Dimitriou, M. D.; Hikita, S. T.; Treat, N. D.; Tirrell, M. V; Clegg, D. O.; Kramer, E. J.; Hawker, C. J. Nat. Chem. 2010, 2 (2), 138-145.

(46) Tarducci, C.; Badyal, J. P. S.; Brewer, S. A.; Willis, C. Chem. Commun. 2005, No. 3, $406-408$.

(47) Gandini, A. Prog. Polym. Sci. 2013, 38 (1), 1-29.

(48) Daugaard, A. E.; Hvilsted, S.; Hansen, T. S.; Larsen, N. B. Macromolecules 2008, 41, 4321-4327.

(49) Hoffmann, C.; Pinelo, M.; Woodley, J. M.; Daugaard, A. E. Biotechnol. Prog. 2017.

(50) De Smidt, O; Du Preez, J. C.; Albertyn, J. FEMS Yeast Res. 2008, 8 (7), 967-978.

(51) Obert, R.; Dave, B. C. J. Am. Chem. Soc. 1999, 121 (6), 12192-12193.

(52) Luo, J.; Meyer, A. S.; Jonsson, G.; Pinelo, M. Bioresour. Technol. 2013, 147, 260-268.

(53) Cochrane, F. C.; Petach, H. H.; Henderson, W. Enzyme Microb. Technol. 1996, 18 (5), $373-378$.

(54) Jadhav, S. B.; Bankar, S. B.; Granström, T.; Ojamo, H.; Singhal, R. S.; Survase, S. a. Appl. Microbiol. Biotechnol. 2014, 98 (14), 6307-6316.

(55) Guldu, O. K.; Ece, S.; Evran, S.; Medine, E. I.; Demirkol, D. O.; Unak, P.; Timur, S. J. Macromol. Sci. Part A 2014, 51 (9), 699-705. 